Journal of Health Promotion and Public Health (2018), 3(1): 56-65

https://doi.org/10.26911/thejhpb.2018.03.01.06

\title{
Socioeconomic Factors and Sexual Behavior Associated with HIV Infection in Population, in Kebumen District, Central Java
}

\author{
Tri Subaeti'), Argyo Demartoto²), Bhisma Murti') \\ 1)Masters program in public health, Universitas Sebelas Maret \\ 2)Faculty of Social and Political Sciences, Universitas Sebelas Maret
}

\begin{abstract}
Background: Globally, the number of people infected with Human Immuno-deficiency Virus (HIV) was estimated at 36.7 million. This study aimed to examine the social economic determinants of HIV status in Kebumen district community.

Subjects and Method: This was an analytic observational with a case-control design. This study was conducted in Kebumen District, Central Java, from January to February 2018. A sample of 81 HIV positive cases and 162 negative controls were selected for this study by fixed disease sampling. The dependent variable was HIV status. The independent variables were age, sex, marital status, income, education, ignorance of the HIV status, health worker support, number of sexual partners, and sexual transmitted infection (STI). Data on HIV status were taken from medical record. The data of other variables were collected by questionnaire. The data were analyzed by logistic regression.

Results: HIV positive status increased with higher income $(\mathrm{OR}=2.94 ; 95 \% \mathrm{CI}=1.04$ to 8.26 ; $\mathrm{p}=$ 0.041), age $\geq 24$ years $(\mathrm{OR}=4.33 ; 95 \% \mathrm{CI}=1.19$ to $15.8 ; \mathrm{p}=0.026)$, ignorance of HIV status $(\mathrm{OR}=0.21 ; 95 \% \mathrm{CI}=0.09$ to $0.51 ; \mathrm{p}=0.001)$, lack of health worker support $(\mathrm{OR}=5.62 ; 95 \% \mathrm{CI}=$ 0.88 to $35.58 ; \mathrm{p}=0.067)$, multiple sexual partner $(\mathrm{OR}=6.59 ; 95 \% \mathrm{CI}=2.69$ to $16.18 ; \mathrm{p}<0.001)$, and presence of STI $(\mathrm{OR}=14.19 ; 95 \% \mathrm{CI}=5.06$ to $39.85 ; \mathrm{p}<0.001)$.

Conclusion: HIV positive status increases with higher income, age $\geq 24$ years, ignorance of HIV status, lack of health personnel support, multiple sexual partner, and presence of STI.
\end{abstract}

Keywords: socioeconomic, determinant, HIV

\section{Correspondence:}

Tri Subaeti. Masters Program in Public Health, Universitas Sebelas Maret. Jl. Ir. Sutami No. 36 A, 57126, Surakarta, Central Java. Email: etisoegito@gmail.com. Mobile: +6281226785111.

\section{BACKGROUND}

The world has committed itself to end the epidemic of Acquired Immune Deficiency Syndrome (AIDS) by 2030. People suffering from Human Immunodeficiency Virus (HIV) are estimated to be about 36.7 million by 2017 (WHO, 2017). People who die of HIV disease are about 1 million by 2016 and 35 million people die from HIVrelated illnesses since the beginning of the epidemic (CDC, 2017). To end the growing HIV epidemic every year, 90-90-90 targets cover $90 \%$ of people living with HIV know their HIV status, 90\% of people who know their HIV status receive Antiretroviral
Therapy (HAART) and 90\% of people receiving ART are testviral loads (World Health Organization, 2016).

The cumulative number of HIV / AIDS patients in Indonesia from 1987 to 2016 were to 232,323 people (Spiritia, 2017). Based on the at-risk group, HIV cases in Indonesia were most prevalent in heterosexuals by $67.6 \%$, injection drug by $10.9 \%$, and homosexuals by $3.3 \%$. Transmission of HIV is at most 20-29 years of age, whereas most cases of HIV in heterosexual men aged 20-49 years and groups of housewives (Ministry of Health RI, 2017). 
In Central Java, HIV / AIDS cases are about 17,641 cases from 1993 to March 2017. There have been 756 Clinical and Testing Services (KT) of HIV in up to 2017. Target Minimum Service Standards (SPM) of Central Java for people who tested HIV is 531,838 people (Central Java Provincial Health Office, 2017).

Kebumen regency ranks first in the discovery of HIV sufferers in Central Java from 2017 to July (Central Java Provincial Health Office, 2017). In Kebumen district, recorded from 1993 to August 2017, there are 854 people living with HIV / AIDS with 231 deaths (27\%). Kebumen District already has 42 VCT facilities, namely 6 Hospitals, 1 UP 3 and 35 Health Centers (Kebumen District Health Office, 2017).

Deressa et al., (2016) in her Ethiopian study found $17.1 \%$ of the subjects of VCT for HIV seropositive results, risk factors for women, widows, marriage, illiteracy, and older age. Racism, discriminatory policy practices, high rates of sexually transmitted diseases, high HIV cases, low levels of education, lack of coverage of health services, and high unemployment remain a problem in America (Sutton et al., 2017). SalazarAustin et al. (2017) states that the most atrisk age is the age of 18-24 years, this is because of the high-risk sexual behavior of HIV incidence. Positive attitudes toward HIV status, positive perceived benefits, external motivation and social support influenced the decision for VCT testing on commercial sex workers (CSWs) in Grobogan (Perdana et al., 2016). VCT is a comprehensive model of information delivery and support to change risky behavior and prevent HIV/AIDS transmission (Demartoto et al., 2017).

The number of studies that show the relationship between social and economic factors to the incidence of HIV, makes researchers interested to determine the influence of socioeconomic and sexual behavior on HIV status in the community of Kebumen District.

\section{SUBJECTS AND METHODS \\ 1. Research Design}

This study is an analytic research using an observational study design with a case study control study design. The study was conducted at Community Health Centes that provided VCT service in Kebumen District, Central Java, Indonesia in January-February 2018.

\section{PopulationandSamples}

The source population in this study was the entire community who conducted VCT in 2017. The case population was those who conducted the HIV-positive VCT test result of 81 samples. The control population was the person who performed the HIV-negative VCT result of 162 samples. The sampling used was fixed disease sampling technique.

\section{Variables}

The dependent variable is HIV status. The independent variables are age, sex, marital status, education, income, desire to know HIV status, change of partner and infectious diseases Infectious Transmitted Infection (STI).

\section{Operational definition of variables}

HIV status was defined as the result of examination of VCT test in VCT service. It was taken from the result of laboratory examination.

Gender was defined as whether they are male or female. The data measurement scale was categorical. Age was defined as how long they life since the birth until the date of the interview. The measurement scale was continuous.

Marital status was defined as the legal marriage status. The data measurement scale was categorical. Education was defined as based on the last diploma. The data 
Journal of Health Promotion and Public Health (2018), 3(1): 56-65

https://doi.org/10.26911/thejhpb.2018.03.01.06

measurement scale was categorical. Income was defined as the money earned by the household every month. The data measurement scale was continuous.

The desire to know the status of HIV was defined as a self-induced urge to know the status of HIV. The data measurement scale was categorical. Behavior of changing partner was defined as the behavior of the subjects who change their partners and the sexual activity they have. Suffering STIs was defined as subjects have ever suffered from STIs.

\section{Study Instruments}

The research instrument used for data collection is questionnaire. The validity test was in the form of content and face validity. The reliability test in this study was done on 20 patients who performed VCT in VCT Service of Public Health Center of Kebumen Regency. The reliability test was performed by measuring the variables using the SPSS 22 statistical program which can calculate the total-item correlation $(\geq 0.20)$ and Cronbach alpha $(\geq 0.70)$.

\section{Data Analysis}

The data analysis was done using logistic regression analysis to determine the magnitude of the influence of risk factors.

\section{Research Ethics}

The research ethics include informed consent, anonymity, confidentiality and ethical clearance. Ethical clearance in this study was conducted in Dr. Moewardi hospital Surakarta.

\section{RESULTS}

\section{Subjects Characteristics}

The characteristics of subjects in the study group of 81 subjects and control groups were 162 subjects. The frequency distribution of the characteristics of the study subjects is described in Table 1.

Based on Table 1, the age of most research subjects aged $\geq 24$ years or $82 \%$ and most of the subjects were women for about $67 \%$. Most subjects' marital status is married at $66 \%$. The level of education of the subjects varies where most of the subjects are high school graduateie 37\% and at least university that is for about $8 \%$. The research subject's income has the most income above the average of $\mathrm{Rp} 1,433,000$ for $72 \%$. The subjects are mostly housewives that are equal to $42 \%$ and at least soldier/police that is equal to $1 \%$.

Table 1. Samples Characteristics

\begin{tabular}{|c|c|c|}
\hline $\begin{array}{c}\text { Subjects } \\
\text { Characteristics }\end{array}$ & $\mathbf{n}$ & (\%) \\
\hline \multicolumn{3}{|l|}{ Age } \\
\hline$<24$ years old & 43 & 18 \\
\hline$\geq 24$ years old & 200 & 82 \\
\hline \multicolumn{3}{|l|}{ Gender } \\
\hline Male & 81 & 33 \\
\hline Female & 162 & 67 \\
\hline \multicolumn{3}{|l|}{ Marital Status } \\
\hline Single & 58 & 24 \\
\hline Married & 160 & 66 \\
\hline Widow/Widower & 25 & 10 \\
\hline \multicolumn{3}{|l|}{ Education } \\
\hline Pre-school & 55 & 23 \\
\hline Junior high school & 78 & 32 \\
\hline Senior high school & 90 & 37 \\
\hline University & 20 & 8 \\
\hline \multicolumn{3}{|l|}{ Income } \\
\hline$<\operatorname{Rp} 1,433,000$ & 68 & 28 \\
\hline$\geq \operatorname{Rp} 1,433,000$ & 175 & 72 \\
\hline \multicolumn{3}{|l|}{ Occupation } \\
\hline Housewife & 101 & 42 \\
\hline Student & 10 & 4 \\
\hline Civil Servant & 10 & 4 \\
\hline Soldier/Police & 1 & 1 \\
\hline Farmer/Sailor/Labor & 42 & 17 \\
\hline Cruise/WPSTL & 3 & 1 \\
\hline Private Sector Worker/ & 8 & 3 \\
\hline employee & 37 & 15 \\
\hline Entrepreneur & 11 & 5 \\
\hline Seller & 20 & 8 \\
\hline
\end{tabular}


Table 2. Chi-Square test between age, sex, marital status, education, income, desire to know about the HIV status, changing partners behavior and STI pain and the HIV status

\begin{tabular}{|c|c|c|c|c|c|c|c|}
\hline \multirow[t]{2}{*}{ Variable } & \multicolumn{2}{|c|}{ Case } & \multicolumn{2}{|c|}{ Control } & \multirow{2}{*}{$\mathbf{O R}$} & \multirow{2}{*}{ CI 95\% } & \multirow{2}{*}{$\mathbf{p}$} \\
\hline & $\mathbf{n}$ & $\%$ & $\mathbf{N}$ & $\%$ & & & \\
\hline Age & & & & & 3.02 & & 0.009 \\
\hline$<24$ years old & 36 & 83.7 & 7 & 16.3 & & & \\
\hline$\geq 24$ years old & 126 & 63 & 74 & 37 & & 1.28 to 7.13 & \\
\hline Gender & & & & & 3.13 & & 0.033 \\
\hline Female & 122 & $75 \cdot 3$ & 40 & 24.7 & & & \\
\hline Male & 40 & 49.4 & 41 & 50.6 & & 1.78 to 5.491 & \\
\hline Marital Status & & & & & 0.52 & & 0.033 \\
\hline Never been married & 32 & 55.2 & 26 & 19.3 & & & \\
\hline Married & 130 & 70.3 & 55 & 61.7 & & 0.28 to 0.95 & \\
\hline Education & & & & & 1.79 & & 0.036 \\
\hline High & 81 & 73.6 & 29 & 26.4 & & & \\
\hline Low & 81 & 60.9 & 52 & 39.1 & & 1.04 to 3.10 & \\
\hline Income & & & & & 3.96 & & $<0.001$ \\
\hline Low & 58 & $85 \cdot 3$ & 10 & 14.7 & & & \\
\hline High & 104 & 59.4 & 71 & 40.6 & & 1.90 to 8.27 & \\
\hline $\begin{array}{l}\text { Desire to know about the HIV } \\
\text { status }\end{array}$ & & & & & 0.38 & & $<0.001$ \\
\hline Yes & 47 & 52.8 & 42 & 47.2 & & & \\
\hline No & 115 & 74.7 & 39 & $25 \cdot 3$ & & 0.22 to 0.66 & \\
\hline Changing partners behavior & & & & & 12.07 & & $<0.001$ \\
\hline No & 134 & 85.4 & 23 & 14.6 & & & \\
\hline Yes & 28 & 32.6 & 58 & 67.4 & & 6.42 to 22.7 & \\
\hline The History of STIs disease & & & & & 22.89 & & $<0.001$ \\
\hline No & 154 & 80.6 & 37 & 19.4 & & 9.94 to & \\
\hline Yes & 8 & 15.4 & 44 & 84.6 & & 52.73 & \\
\hline
\end{tabular}

Table 3. Multiple logistic regression analysis of risk factors for HIV status

\begin{tabular}{|c|c|c|c|}
\hline Variable & $\mathbf{O R}$ & CI 95\% & $\mathbf{p}$ \\
\hline Age $\geq 24$ years old & 4.33 & 1.19 to 15.80 & 0.026 \\
\hline Gender - male & 1.14 & 0.39 to 3.28 & 0.815 \\
\hline Marital Status & 1.41 & 0.47 to 4.30 & 0.536 \\
\hline Low education & 1.87 & 0.82 to 4.28 & 0.14 \\
\hline High Income & 2.94 & 1.04 to 8.26 & 0.041 \\
\hline No desire about HIV status & 0.2 & 0.09 to 0.51 & 0.001 \\
\hline Changing partner behavior & 6.59 & 2.68 to 16.18 & $<0.001$ \\
\hline STIs disease & 14.19 & 5.06 to 39.85 & $<0.001$ \\
\hline \multicolumn{4}{|l|}{ N Observed $=243$} \\
\hline \multicolumn{4}{|l|}{-2 Log likelihood $=166.58$} \\
\hline Nagelkerke R Square $=61.7 \%$ & & & \\
\hline
\end{tabular}

\begin{tabular}{l} 
DISCUSSIONS \\
\hline 1. The Effect of Age on HIV Status \\
Based on the study, there was a meaningful \\
relationship between age and positive HIV \\
status. The result of multivariate analysis \\
showed that age $\geq 24$ years old increased
\end{tabular}

\section{DISCUSSIONS}

1. The Effect of Age on HIV Status

Based on the study, there was a meaningful showed that age $\geq 24$ years old increased the risk of positive HIV. Research subjects who were $\geq 24$ years old increased 4.33 times for positive HIV status. The older a person to has the behavior, lifestyle and social interaction with many people, it can affect the health which in this case was HIV. The proportion of HIV-infected adults 
Journal of Health Promotion and Public Health (2018), 3(1): 56-65

https://doi.org/10.26911/thejhpb.2018.03.01.06

in southwestern Nigeria increased at above 50 years old,this was due to the very high prevalence of opportunistic infections and was associated with low $\mathrm{CD} 4$ and the occurrence of hepatitis $\mathrm{C}$ co-infection (Akinyemi et al., 2017).

Similar idea was also stated by Awofala \& Ogundele (2015), incidence of HIV infection was higher in women, age group of 35-44 years old with occupation. Dias et al., (2018) stated that a widow with high income, aged 25-29 years old, was more likely to have positive HIV because of the multiple sexual partners behavior. The productive age group of 25-39 years old, educated, and higher incomes have a higher chance of getting HIV infection compared to the low-educated and poor category (Lakew et al., 2015).

Age was associated with HIV status, the older the age of a person, the higher the risk of positive HIV.This was due to the behavior, lifestyle, and social interaction with many people that it can affect the health which in this case was HIV.

\section{The Effect of Gender on HIV Status}

Based on the result of this study, there was no meaningful relationship between gender and positive HIV status. The result of multivariate analysis showed that male gender increased the risk of positive HIV. Research subjects who were male increased the risk by 1.14 times for positive HIV status.WHO (2007) stated that in the whole world, the seropositive level was generally higher in women than in men. However, a study in Mwanza, Tanzania, showed that HIV infection in men was higher than in women because of herpes simplex virus type 2.

This study was in accordance with a study done byDunkle et al. (2013)which stated thatviolence and harassment of sex workers (men who like men) increased HIV risk in Shanghai, China. 35-44 years old men have a higher prevalence of HIV infection in Nigeria (Awofala and Ogundele, 2015).

Gender was not associated with HIV status, but male has a greater chance to have HIV. Based on PRECEDE PROCEED's theory of environmental impact evaluation, men have a greater chance, therefore, it affected their health and quality of life.

\section{The Effect of Marital Status on HIVStatus}

Based on the study, there was no meaningful relationship between marital status and positive HIV status. The result of multivariate analysis showed that married people increased their risk of getting positive HIV. Research subjects who have been married increased the risk by 1.41 times on positive HIV status. In Zimbabwe, HIV increased nearly 2 times greater due to marriage and those who lived together were likely to have unprotected sexual activity, therefore, it increased the risk of getting HIV and other sexually transmitted diseases (Kembo, 2012).

This study was in accordance with a study done by Rojas et al. (2016), which stated that there was a relationship between marital status and the incidence of HIV in Latin America. Fagbamigbe et al., (2016) also stated that HIV infection was 1.8 times higher among women who have been married compared to women who never married. Positive HIV patients in North Ethiopia have risky sexual practices, married and aged 18-39 years old (Molla and Gelagay, 2017).

Marital status was not related to HIV status, however, the research subject who has been married has a greater chance of getting HIV. This was because married people did not use condoms in doing sexual activity, therefore, it increased the risk of HIV. 


\section{The Effect of Education on HIVStatus}

Based on the study, there was no meaningful relationship between education and positive HIV status. The result of multivariate analysis showed that low level of education increased the risk of getting positive HIV. Research subjects with low education increased the risk by 1.87 times on positive HIV status. Highly-educated people tend to check their HIV status compared to those with low education (Alemu et al., 2017).

This study was in accordance with a study done by Chanda-Kapata et al., (2016), in his research in Zambia, it was found that HIV risk was lower among students compared to those who were unemployed and not attending school Teklehaimanot et al., (2016). Young and highly educated rural men and women have a lower risk of HIV infection in Ethiopia. In a study by Karkashadze et al., (2017), it was also stated that most of the HIV patients were loweducated people.

Shittu et al. (2014) in his study in Nigeria, West Africa, found that HIV sufferers mostly have lack of education from middle school. García et al., (2017) found thattruck drivers in Peru were at lower risk of HIV infection, due to older age, higher education, higher income, and spending more time at home.

Education was not related to HIV status, but low education has a greater chance of getting HIV. According to PRECEDE PROCEED's theory about the evaluation of behavioral and lifestyle impacts, educational levels may be related to the ability to absorb and receive health information, and it contributed to changes in health behavior. Knowledge that was affected by the level of education was one of the factors that played a role in influencing a person's decision to behave healthily.

\section{The Effect of Income on HIVStatus}

Based on the study, there was a meaningful relationship between income and positive HIV status. The result of multivariate analysis showed that high income increased the risk of getting positive HIV. Research subjects with high income increased 2.94 times on positive HIV status. High income played as one of predisposition changes in behavior and lifestyle that were at risk on health.Arnold et al., (2011)in his research in the United States stated that a consistent or significant relationship between socioeconomic and risky behavior cannot be identified. However, with an enhancement of the economy, it can affect self ability or lifestyle that can lead to risky behavior.

This study was in accordance with a study done by Salazar-Austin et al. (2017) which stated that higher education, higher socio-economic, and marriage were the factors that can increase HIV status. Educated and richer groups have a higher chance of becoming infected by HIV than the poor and low-educated population category (Lakew et al., 2015). Income was associated with HIV status, high incomes have a greater chance of getting HIV. Based on PRECEDE PROCEED theory on the evaluation of behavioral and lifestyle impacts, high incomes were related to the ability of people's purchasing power, lifestyle, and environment to contribute to changes in health behavior.

\section{The Effect of the Intention to Know the Status on HIVStatus}

Based on the study, there was a meaningful relationship between the desire or intention to know the status and positive HIV status. The result of multivariate analysis showed that the lack of a desire to know the status decreased the risk of positive HIV. No desire to know the status decreased the risk by 0.2 times on positive HIV status. The 
Journal of Health Promotion and Public Health (2018), 3(1): 56-65

https://doi.org/10.26911/thejhpb.2018.03.01.06

low self-strengthening factors would influence the health behavior that affected the quality of life. Positive attitudes toward HIV status, positive benefits, external motivation, and social support positively affected the VCT test for HIV status (Perdana et al., 2016).

This study was in accordance with a study done by Xu et al. (2017), which stated that patients who want to know the status of HIV would be able to live their lives if they have family support and there was no discrimination. The prevalence of HIV infection among MSM who have high selfperceptions for HIV infection encouraged the desire to know the status of HIV (Torres et al., 2017)

In a study in India, components of macroeconomic vulnerability showed that educational levels, employment status, HIV awareness, and the area in which they live have an impact on HIV transmission (Lall, 2014). The main factors of people to do VCT test to find out the status of HIV were due to the decreased of physical health, death of a sexual partner or child (Musheke et al., 2013).

The desire to know the HIV status has a significant relationship with positive HIV status, people have no willingness to do a VCT test because they did not know the benefits gained and no family who was suffering from HIV. This study supported the theory of PRECED-PROCEED (Reinforcing factor) which explained that with the exposure of HIV, it can encouraged the community to do VCT to know the status of HIV.

\section{The Effect of Having Multiple Partners on HIV Status}

Based on the study, there was a meaningful relationship between having multiple partners and positive HIV status. The result of multivariate analysis showed that having multiple partners increased the risk of getting positive HIV. The study subjects who had multiple partner behavior increased the risk by 6.59 times on HIV status. With risky behavior and lifestyle, it would increase health problems especially for HIV disease. The number of sexual partners played a role in HIV transmission (Pouget, 2017).

This study was in accordance with a study done by Martins-Fonteyn et al., (2017), which stated that miners who have more than one sexual partner have three times higher risk of HIV transmission. Botão et al., (2016) in his study in longdistance truck drivers in Mozambique found a high prevalence of HIV caused by having four sexual partners and not using condoms. Gelaw et al., (2015) obtained the reason of the patients to do the test to know the HIV status was having multiple sexual partners.

Health problems related to sexual behavior were at risk of HIV infection (Adilo and Wordofa, 2017). A person's sexual behavior was influenced by his/her relationship with others, the environment, and the culture in which the individual lived (Demartoto, 2013).Multiple partners behavior has a significant relationship with positive HIV status. This was because having multiple partners allowed a person to be more susceptible to HIV.According to the PRECEDE-PROCEED theory of environmental impact evaluation, behavior and lifestyle greatly affected the health.

\section{The Effect of STD on HIV Status}

Based on the study, there was a meaningful relationship between STD and positive HIV status. The result of multivariate analysis showed thatSTD increased the risk of HIV. STD increased 14.19 times on positive HIV status.High-risk sexual behavior was very common, and $16 \%$ of HIV-infected MSM in HIV care suffered the most common 
sexually transmitted disease which was syphilis (Heiligenberg et al., 2012).

This study was in accordance with a study in Puerto Rico which showed that people who have sex with men and HIV women have a history of using alcohol, injecting drugs, having a history of STD, and having free sex for a fee compared to people who have sex with a male only(Ellen et al., 2015). Behavioral history of STD has a significant relationship with positive HIV status. This was because the history of STD was one of the means for someone to easily transmitted by HIV. Based on the PRECEDE-PROCEED theory of environmental impact evaluation, behavior and lifestyle greatly affected the health.

\section{REFERENCES}

Adilo TM\& Wordofa HM (2017). Prevalence of fertility desire and its associated factors among $15^{-}$to 49-year-old people living with HIV/AIDS in Addis Ababa, Ethiopia: a cross-sectional study design. HIV/AIDS - Research and Palliative Care, 31(3), 167-176.

Akinyemi JO, Ogunbosi BO, Fayemiwo AS, Adesina OA, Obaro M, Kuti MA, Adewole IF (2017). Demographic and epidemiological characteristics of HIV opportunistic infections among older adults in Nigeria. African Health Sciences, 17(2), 315-321.

Alemu YM, Ambaw F, \& Wilder-Smith A (2017). Utilization of HIV testing services among pregnant mothers in low income primary care settings in northern Ethiopia: a cross sectional study. BMC Pregnancy and Childbirth, 17(1), 199.

Arnold MP, Fisher HR \& McFarland W (2011). Socioeconomic position and HIV risk-relevant behavior among lower-income heterosexuals in San Francisco. AIDS and Behavior, 15(2),
499-506.

Awofala AA, Ogundele OE (2015). HIV epidemiology in Nigeria. Saudi Journal of Biological Sciences.

Botão C, Horth RZ, Frank H, Cummings B, Inguane $\mathrm{C}$, Sathane I, Young PW. (2016). Prevalence of HIV and Associated Risk Factors Among Long Distance Truck Drivers in Inchope, Mozambique, 2012. AIDS and Behavior, 20(4), 811-820.

CDC. (2017). HIV/AIDS | CDC. Retrieved December 13, 2017, from https://www.cdc.gov/hiv/basics/index.html.

Chanda-Kapata P, Klinkenberg E, Maddox N, Ngosa W, Kapata N (2016). The prevalence and socio-economic determinants of HIV among teenagers aged 15-18 years who were participating in a mobile testing population based survey in 2013-2014 in Zambia. BMC Public Health, 16(1), 1-7.

Deressa T, Sinku Y, Gezahegn T, Gashaw Y, Workineh M (2016). Seroprevalence of human immunodeficiency virus among voluntary counseling and testing clients at the University of Gondar Teaching Hospital, Northwest Ethiopia. HIV/AIDS - Research and Palliative Care. 8: 135-140.

Dias SS, Mbofana F, Cassy SR, Dias S, Augusto GF, Agadjanian V, Martins MRO. (2018). Estimating risk factors for HIV infection among women in Mozambique using population-based survey data. African Journal of AIDS Research, 17(1), 62-71.

Dinkes Kabupaten Kebumen. (2017). Analisa Kasus HIV/AIDS di Kabupaten Kebumen.

Demartoto A (2013). Seks, Gender, Seksualitas Gay dan Lesbian. from http://argyo.staff.uns.ac.id/2013/o4/24/sek s-gender-seksualitas-gay-dan-lesbian/ diakses padaOctober 19, 2017. 
Journal of Health Promotion and Public Health (2018), 3(1): 56-65

https://doi.org/10.26911/thejhpb.2018.03.01.06

Demartoto A, Zunariyah S, Soemanto RB (2017). Pendidikan Sebaya Terstruktur Responsif AIDS. Surakarta: CV. Kekata Group, Surakarta.

Dinkes Prop. Jateng. (2017). Hasil Kegiatan HIV dan AIDS Provinsi Jawa Tengah. Semarang.

Dunkle KL, Wong FY, Nehl PEJ, Lin L, He N, Huang J, Zheng T (2013). Male-onMale Intimate Partner Violence and Sexual Risk Behaviors Among Money Boys and Other Men Who Have Sex With Men in Shanghai, China, 40(5), 362-365.

Ellen JM, Greenberg L, Willard N, Stines S, Korelitz J, Boyer CB. (2015). Crosssectional survey comparing HIV risk behaviours of adolescent and young adult men who have sex with men only and men who have sex with men and women in the US and Puerto Rico: Table 1. Sexually Transmitted Infections, 91(6), 458-461.

Fagbamigbe AF, Adebayo SB, Idemudia E. (2016). Marital status and HIV prevalence among women in Nigeria: Ingredients for evidence-based programming. International Journal of Infectious Diseases, 48, 57-63.

García PJ, Fazio B, Bayer AM, Lizarraga, AG, Chiappe M, La Rosa S, Cárcamo CP. (2017). Sexual health knowledge and practices and STI/HIV prevalence among long-distance truck drivers in Peru. SAGE Open Medicine, 5, 205O31211774630.

Gelaw YA, Senbete GH, Adane AA, Alene KA (2015). Determinants of late presentation to HIV/AIDS care in Southern Tigray Zone, Northern Ethiopia: An institution based case-control study. AIDS Research and Therapy, 12(1), 1-8.

Heiligenberg M, Rijnders B, Van Der Loeff MFS, De Vries HJC, Van Der Meijden
WI, Geerlings SE, Prins JM (2012). High prevalence of sexually transmitted infections in HIV-infected men during routine outpatient visits in the Netherlands. Sexually Transmitted Diseases, 39(1), 8-15.

Karkashadze E, Gates MA, Chkhartishvili N, DeHovitz J, Tsertsvadze T. (2017). Assessment of quality of life in people living with HIV in Georgia. International Journal of STD \& AIDS, 28(7), 672-678.

Kembo J (2012). Risk factors associated with HIV infection among young persons aged 15-24 years: Evidence from an in-depth analysis of the 2005-06 Zimbabwe demographic and health survey. Sahara J, 9(2), 54-63.

Kemenkes RI (2017). Data dan Informasi Profil Kesehatan Indonesia 2016. Jakarta.

Lakew Y, Benedict S, Haile D (2015). Social determinants of HIV infection, hotspot areas and subpopulation groups in Ethiopia: evidence from the National Demographic and Health Survey in 2011. BMJ Open, 5(11), eoo8669. 2015-008669

Lall P (2014). Social Factors Affecting Women's Susceptibility to HIV in India. ABDI Institute.

Martins-Fonteyn E, Loquiha O, BaltazarC, Thapa S, Boothe M, Raimundo I, Wouters E (2017). Factors influencing risky sexual behaviour among Mozambican miners: a socio-epidemiological contribution for HIV prevention framework in Mozambique. International Journal for Equity in Health, 16(1), 179.

Molla AA, Gelagay AA (2017). Risky sexual practice and associated factors among HIV positive adults attending antiretroviral treatment clinic at Gondar University Referral Hospital, North- 
west Ethiopia. PLoS ONE, 12(3), 1-12. Musheke M, Ntalasha H, Gari S, Mckenzie O, Bond V, Martin-Hilber A, Merten S (2013). A systematic review of qualitative findings on factors enabling and deterring uptake of HIV testing in Sub-Saharan Africa. BMC Public Health, 13(1), 220.

Perdana MV, Demartoto A, Indarto D (2016). Effects of Predisposing, Enabling, and Reinforcing Factors on the Uptake of Voluntary Counselling and Testing among Female Sex Workers in Grobogan, Central Java. International Conference on Public Health, 1172: 243-257.

Pouget E (2017). Social determinants of adult sex ratios and racial/ethnic disparities in transmission of HIV and other sexually transmitted infections in the U.S. Philosophical Transactions of the Royal Society of London. Series B, Biological Sciences, 95.

Rojas P, Huang H, Li T, Ravelo GJ, Sanchez M, Dawson C, De La Rosa M (2016). Sociocultural determinants of risky sexual behaviors among adult latinas: A longitudinal study of a communitybased sample. International Journal of Environmental Research and Public Health, 13(11), 1-21.

Salazar-Austin NMK, Chariyalertsak ACS, Srithanaviboonchai K, Gray G, Richter L, Morin $\mathrm{H}$, van RS, Mbwambo MS (2017). Age-Related Differences in Socio-demographic and Behavioral Determinants of HIV Testing and Counseling in HPTN 043/NIMH Project.

Shittu RO, Issa BA, Olanrewaju GT, Mahmoud AO, Odeigah LO \& Sule AG. (2014). Social Determinants of De- pression: Social Cohesion, Negative Life Events, and Depression Among People Living with HIV/Aids in Nigeria, West Africa. International Journal of MCH and AIDS, 2(2), 174-81.

Spiritia (2017). Statistik Kasus HIV/AIDS di Indonesia.

Sutton MY, Gray SC, Elmore K \& Gaul Z. (2017). Social determinants of HIV disparities in the southern United States and in counties with historically black colleges and universities (HBCUs), 2013-2014. PLoS ONE, 12(1), 2013-2014.

Teklehaimanot HD, Teklehaimanot A, Yohannes M, Biratu D. (2016b). Factors influencing the uptake of voluntary HIV counseling and testing in rural Ethiopia: a cross sectional study. BMC Public Health, 16(1), 239.

Torres RMC, Cruz MM, da-Périssé ARS \& Pires DRF. (2017). High HIV infection prevalence in a group of men who have sex with men. Brazilian Journal of Infectious Diseases, 21(6), 596605 .

WHO. (2017). HIV/AIDS. Retrieved from http://www.who./mediacentre/factsheets/fs36o.

(2016). Consolidated guidelines on the use of antiretroviral drugs for treating and preventing HIV infection: recommendations for a public health approach.

Xu JF, Ming ZQ, Zhang YQ, Wang PC, Jing J\& Cheng F. (2017). Family support, discrimination, and quality of life among ART-treated HIV-infected patients: A two-year study in China. Infectious Diseases of Poverty, 6(1), $1-10$. 